\title{
Effect of Female Principal's Management Styles on Teacher's Job Satisfaction in *Isfahan-Iran, Girls High Schools
}

\author{
Rajaeepour Saeed \\ Associate prof, $\mathrm{PhD}$ of Higher Education \\ School of Educational Sciences and psychology, University of Isfahan, Isfahan, Iran \\ Tel: 0098-311-793-2554 \\ Arbabisarjou Azizollah \\ Faculty Member of Zahedan University of Medical Sciences \\ Zahedan School of Nursing and Midwifery, Zahedan University of Medical Sciences, Iran \\ Tel: 0098-541-241-9407Ｅ-mail: arbabisarjou2007@gmail.com \\ Amiri Zahra \\ M.A in Educational Administration \\ School of Educational Sciences and psychology, University of Isfahan, Isfahan, Iran \\ E-mail: Nazanin_712@yahoo.com \\ Nematiniya Abdolghayoum \\ Research Scholar, Department of Sociology, Banaras Hindu University, Varanasi, India
}

Ajdai Zaman

M.A in Educational Administration

School of Educational Sciences and Psychology, University of Isfahan, Isfahan, Iran

E-mail: Ajdarizaman@gmail.com

Yarmohammadzadeh Peyman

Assistant prof, $\mathrm{PhD}$ of Educational Administration

School of Educational Sciences and Psychology

Azarbaiejan University of Tarbiat Moallem, Tabriz, Iran

E-mail: dr.peyman.ymz@gmail.com

Received: January 24, 2011 Accepted: February 14, 2011 doi:10.5539/ies.v4n3p124

\begin{abstract}
Assuring job satisfaction, over a long-term, requires managers' styles, careful planning and effort both by management and by workers. Job satisfaction is influenced by the employee's personal characteristics, the manager's personal characteristics and management style, and the nature of the work itself. The aim of this study was to determine the management styles of female managers based on the four styles of Reddin (directive, executive, benevolent autocrat and bureaucrat) and their effects on job satisfaction of teachers in girls high schools in Isfahan in the academic year of 2006-2007. The research method in this study is correlational descriptive. The participants of this study were 150 teachers in girl high schools which were randomly chosen from 2591 teachers and finally, 125 questionnaires were analyzed. The data collection tools included two researcher-made questionnaires which were about the management styles and job satisfaction, with 37 and 41 questions accordingly. The questions were
\end{abstract}


based on the Likert scale. The validity of the questionnaires was content-based validity and the reliability of the questionnaires was 0.81 and 0.92 , based on the Cronbach Alpha Coefficient. To analyze the data, descriptive analysis (mean, variance, frequency distribution and percent) and inferential analysis (Hoteling t2, Pearson coefficient correlation, independent t-test, multi variance regression and Toki test) were used. The results of the study showed that only directive and executive management styles affect positively the teachers' job satisfaction. Also among the teachers there are different views about the directive style based on their gender and the level of education. In terms of executive style, there is a different view among the teachers based on their teaching experience. There was not a significant difference between the teachers' degree and the kind of high school. Among the demographic factors, only the Kind of high school (governmental or non-profit) was effective on the job satisfaction, which the teachers in the non-profit high schools were more satisfied.

Keywords: Job satisfaction, Management styles, Four styles of Reddin, Principal

\section{Introduction}

Nowadays, education has changed and developed fundamentally due to cultural, social and political changes. Education is under intense scrutiny by public and private interests who question the systems ability to fulfill its goals of teaching basic skills, instilling values, preventing dropouts, and producing a productive workforce. Such an incredible responsibility requires high committed to fulfilling the high expectations. Nurturing and educating the new generation have assigned to educational systems. Today, educational administration means: leadership, directing, reform and change. Therefore, achievement to high level goal of education in each society, demand renovation and reorganization and new thinking in management of educational systems are tasks for educational managers such as school principal's.(Allahabad, 2004). Educational Administration either in supervision and monitoring of financial and official affairs, in education or others that involving directly with development and implementation of educational program, have responsibility and tasks in achievement of essential objectives of educational administration as named facilitating teaching-learning process. Hart (1999) included that job satisfaction contributes to overall life satisfaction. According to Edward Lawler (1973), Job satisfaction is a measure of the quality life in our organization. It seems important for managers to understand the components of the quality of work life and they know how to treat with coworkers.

Job satisfaction is critical to retaining and attracting well-qualified principals and teachers in educational environment. Job satisfaction can define as an employee's affective reaction to a job, based on a comparison between actual outcomes and desired outcomes (Mosadeghrad \& Yarmohammadian, 2006).

Schools must give more attention to teacher job satisfaction because it may promote efficiency and staff satisfaction. One of the important factors in improvement of psychological and spiritual energy for staff in the organization is promotion of job satisfaction in teachers. In fact, job satisfaction is a kind of emotional and affective coping with job and its conditions, it consists of two components: cognitive and behavioral. The cognitive aspect is an indicator for staff believes about their job conditions while behavioral aspect means individuals trends to their job. Cognitive aspect has more validity than other behavioral aspects due to further relationship with individuals' attitudes. A successful education system dependent upon a high quality teaching staff. In order to develop this high quality teaching staff, one must look at factors associated with teacher quality and retention. One of these factors is teacher job satisfaction. Job satisfaction can be defined as an overall feeling about ones job or career in terms of specifies, i.e. compensation, autonomy, coworkers; administration. Job satisfaction has been studied for many years. Happock (1935) was one of the first researchers to study job satisfaction. He found that workers were more satisfied with a supervisor who was understanding and helpful (as in cited, Bass, 1990). Frederick Herzberg (1959), psychologist and researcher studied job satisfaction because he believed higher satisfaction led to higher productivity, decreased absenteeism, and better working relations. He found that positive feeling about work, a sense of personal worth, and a sense of personal fulfillment were related to achievement and responsibility (Wetherell, 2002).

Lurnsden (1998) reported on job satisfaction among teachers. Teachers identified administrative support, leadership, good student behavior, a positive school atmosphere, and teacher autonomy as factors associated with higher job satisfaction. Parental support and workplace conditions were also positively related to job satisfaction. Salaries and benefits were found to be weakly related to job satisfaction. Derlin and Schneider (1994) studied job satisfaction of both principals and teachers. In their research, they found that, in urban areas, job satisfaction was most affected by teacher school climate and working conditions. In suburban areas, the most important factor was teacher involvement and empowerment. Winter and Sweeny (1994) also found that climate affects satisfaction. They identified areas in which administrators could focus on in order to improve climate. These were recognizing achievement, supporting teachers, encouragement, caring, and fairly enforcing school rules. Anderman et al. (1991) studied both school culture and principal leadership and its effect on job satisfaction. The analysis of the study 
showed that accomplishment, recognition, and affiliations were related to job satisfaction. The results indicated that principal's leadership behavior fostered different perceptions of teachers on school culture, and also in teacher satisfaction and commitment.

Reddin (1970) introduced a model of leadership style containing four basic types, namely; Integrated, related, dedicated, and separated. Further, by measuring the level of effectiveness of each style Reddin developed this basic model into eight leadership styles. The modified model is called "The 3-D Theory of Managerial Effectiveness". It can be seen that the four less effective styles are Deserter, Missionary, Autocrat, and compromiser, while the executive are briefly described as follows:

i. Bureaucratic style is a legalistic and procedural approach, adherence to rules and procedures; acceptance of hierarchy of authority; preference of formal channels of communication. They function at their best in well-structured situations where policies are clear, roles are well defined and criteria of performance are objective and universally applied because they insist on rational systems.

ii. Developer style is concern with people development professionally; subordinates are allowed to participate in decision making and are given opportunities to express their views, to develop their potential and trusts people. They have optimistic beliefs about people wanting to work and produce.

iii. Benevolent autocrat leader is still directive and interventionist. These leaders enjoy tackling operational problems and may have less patience dealing with problems of human relations. They keep in touch with subordinates, instructing them, answering their questions and helping them with operational problems. They structure daily work, set objectives, give order or delegate with firm accountability.

iv. Executive style integrates task orientation and human relations orientation in response to realistic demand. It is best described as consultative, interactive, and problem solving approach. They favor a team approach in problem solving, planning and decision making. They stimulate communication among subordinates, thus obtain collective ideas and suggestions for collective commitment.

Human resources are very important in educational systems due to their absorption, training and maintenance as human capital. Hence, teachers' efficiency and job satisfaction are important issues that have pivotal role in development of educational systems. Undoubted, teachers demand satisfaction in their work, uses their skills in their work and does their best.

In general, job satisfaction is one of human motivation issues in the human resource management but some theories such as needs hierarchy, equity, achievement, and two-factor theory of motivation argue it.

Despite the importance of job satisfaction and its effects on management styles, there are not enough researches particularly on female management styles based on Reddin model. This research was carried out to assess female management styles based on Reddin model and its effects on job satisfaction of female teachers of girl high school in Isfahan-Iran. If women have more responsibilities in the community affairs, they may get more and better position in the institutions and in states. Half of Schools have female managers and they manage and monitor human, material and financial resources and their exploitation depend on their management. In this research, we used related job satisfaction theories particularly two-factor of Herzberg. Management and leadership are essential for many aspects of social life and educational organization, it is more important, also staff job satisfaction is one of the most disputable issues in management. Teachers, in the educational systems, have pivotal role, therefore their job satisfaction is a key issues in the management and leadership because their satisfaction improve education, teachinglearning process and student achievement. Satisfied teachers, have better efficacy and then it will has positive effect on education quality.

The overall importance of this study is as a result of the pivotal role of educational managers and leaders on teacher's job satisfaction and then focus on the importance and effect of job satisfaction on students learning. Moreover, this research and similar researches may provide the background for seeking and finding behavioral styles and patterns of female managers in educational systems with determining of behavioral patterns of female managers, we can analysis the behavioral styles and patterns which can help us for reproduction, notation and improvement of existence styles. At least, this research is an effort to present some suggestions to improve management styles and increasing teachers job satisfaction in the schools.

\section{Review of Literature}

Based on Locke (1976) review of empirical studies on job satisfaction, he determined that seven work issues are specially associated with job satisfaction, which these are: individual interest in the special job, mentally challenging job, work that is not too physically tiring, perceived equitable rewards, appropriate working conditions, employee 
self-esteem, management collaboration in managing the workplace and ensuring that work is interesting and good pay/promotions are accessible.

Among determinants of job satisfaction, management/leadership style is assessed as an important predictor and has a pivotal role. Several researches have done in many countries, concluded that there was a positive correlation between leadership style and the Job satisfaction (Vance \& Larson, 2002; Dunham-Taylor, 2000; Chiok Foong Loke, 2000; Berson \& Linton, 2005, Mosadeghrad \& Yarmohammadian, 2006).

Organizational success for its goals achievement depends on managers and their leadership style. By using appropriate leadership or management styles, managers can affect employee job satisfaction, commitment and productivity. Management style is combination of managerial behaviors, attitudes, characteristics, and skills based on individual and organizational values, leadership interests and reliability of employees in different situations (Mosadeghrad, 2003).

Bogler (2001) in his research titled "the influence of leadership style on teacher job satisfaction" examined the effects of principals' leadership style (transformational or transactional), principals' decision-making strategy (autocratic versus participative), and teachers' occupation perceptions on teacher satisfaction from the job. More specifically, it attempts to find out how much of the variation in teachers' job satisfaction can be attributed to their perceptions of their occupation, as compared to their perceptions about their principals' leadership style and decision-making strategy. Path analysis was used to explain teacher job satisfaction by the exogenous variables. The most salient finding was that teachers' occupation perceptions strongly affect their satisfaction. Principals' transformational leadership affects teachers' satisfaction both directly and indirectly through their occupation perceptions. Tsai (2008) carried out a research about the correlation between the style of managerial leadership and employee's job satisfaction in the international tourist hotel industry. The findings showed that employees are more satisfied under consideration-style-leadership than construction-style-leadership. After controlling for differences in salary, employees appear to prefer consideration-style-leadership. No matter what the leadership style is, employees' job satisfaction does not relate towards their coworkers. Besides, employees have different perceptions on work, salary, and overall satisfaction depending on their education level and seniority. Lucas (1991), in his research on nurses determine nurses' perceptions of the current and desired management styles of hospital units and to investigate the relationship of management style with job satisfaction, he found that the staff nurses were currently experiencing a benevolent-authoritative management style, but preferred a participative style. Management style and job satisfaction were significantly correlated $(\mathrm{r}=0.6050)$. Management style perception scores predicted 36.6 percent of the variance in job satisfaction scores. Faille and Stichler (2008) in their study titled "Manager and staff perceptions of the manager's leadership style" found that nurses' job satisfaction is a critical element in addressing the nursing shortage. Literature supports that job satisfaction is related to nurse manager leadership style. This fact has caused nurse managers to carefully consider their leadership style and the impact it has on the nurses they manage. A correlation was found between nurse manager transformational leadership style and nurse job satisfaction $(\mathrm{r}=0.348, \mathrm{P}<0$.05). Transformational leadership style was associated with higher levels of job satisfaction. The findings added to the knowledge about variables that are correlated with job satisfaction, which is a critical issue to nursing. Sellgrens et al. (2006), in a study of leadership styles in nursing management: preferred and perceived, explored nursing leadership regarding what nurse managers and subordinates sees as important and to explore subordinates' opinions of their nurse manager's performance in reality. The manager's style can be fundamental for subordinates' acceptance of change and in motivating them to achieve stated visions and goals and high quality of care. Results showed that there are statistically significant differences in opinions of preferred leadership between managers and subordinates, especially related to production and relation orientation. The subordinates' perception of real leadership behavior has lower mean values than their preferred leadership behavior in all three dimensions. Subordinates prefer managers with more clearly expressed leadership behavior than managers themselves prefer and demonstrate. Mehrotra (2001) found that the principals of government and private schools manifest different leadership styles. The majority of the government school principals have low initiation high consideration (LH) style. While majority of private school principals have a unique high initiation - high consideration pattern (Mehrotra, 2005). On comparing the mean scores of government and private school principals, no significant difference was found between the leadership styles of the principals in these two types of schools. And the data reveal that in government schools $46.4 \%$ teachers are highly satisfied. $35.7 \%$ teachers are moderately satisfied and only $17.8 \%$ teachers are low satisfied. Bogler (2002), in his study of two profiles of school teachers: a discriminate analysis of job satisfaction, attempted to construct profiles of two types of teachers: those with a low level of job satisfaction and those with a high level of job satisfaction. In addition to their background and demographic characteristics, teachers' perceptions of their occupation and of their principals' leadership styles (transformational or transactional) are examined as predictors that discriminate between teachers with low and high 
levels of satisfaction. The results suggest that teachers with a low level of satisfaction can be reliably distinguished from teachers with a high level of satisfaction by their occupational perceptions, principals' leadership styles, and a number of their demographic characteristics. Barnett (2005), in his study examined the impact of transformational leadership style of the school principal on school learning environments and selected teacher outcomes, examines the effects of different types of secondary principals' leadership behaviors on aspects of a school's learning environment, and selected teacher outcomes. Study one involved a quantitative analysis of teachers' perceptions of principals' leadership style, school learning environment and selected teacher outcomes. Study two involved a qualitative analysis of data collected from 12 respondents in three schools, examining those leadership practices that enhanced or eroded teachers' perceptions of school learning environment and teacher satisfaction. Specifically, the qualitative phase of the study was used to investigate those specific principal leadership behaviors that enhance both teacher outcomes and perceptions of school learning environment. In his study a synergy was achieved by undertaking two studies drawing upon a multi-method approach. While some transformational leadership behaviors of vision building were demonstrated to be effective in influencing school learning environment and teacher outcome variables, it was a combination of transformational and transactional leadership styles that demonstrated the most impact in relation to school learning environment and teacher outcomes. Parkinson (2008) investigated the relationship between the perceived leadership style of the principal and late career teacher job satisfaction. There was a significant relationship between the perception of idealized influence and extrinsic satisfaction. A significant relationship was also found between contingent reward and intrinsic satisfaction. Qualitative data from individual teacher interviews supported these findings. The overall findings from this study suggest that late leadership styles impact intrinsic and extrinsic satisfaction. More specifically, some transformational and transactional variables had a positive impact on job satisfaction. These findings suggest that a balance of transactional and transformational leadership styles may be most effective for school leaders wishing to improve the satisfaction of late career teachers.

Conducting this study, would provide further information about this issue for educational authorities. In respect to this issue, the research questions are:

i) What are the female managers' management styles?

ii) Is there any relationship between developer management style and job satisfaction?

iii) Is there any relationship between executive management style and job satisfaction?

iv) Is there any relationship between benevolent management style and job satisfaction?

v) Is there any relationship between bureaucrat management style and job satisfaction?

\section{Methodology}

This study was designed to determine if there is a relationship between female mangers management style and teacher job satisfaction.

This is a descriptive correlation and cross sectional survey. This study focused on girl high schools in Isfahan, Iran, in which the managers had been at the girl high schools for at least on complete school year. The decision to limit the managers' sample to those who had been at the site for at least one complete year was to ensure they had time to affect teacher job satisfaction. Statistical populations were 2591 female teachers of girl high schools in the Isfahan city for 2006-2007 school-years. After doing a pilot study and multi-stage randomized sampling, 150 teachers were selected and ultimately 125 managers completed questionnaires for a return rate of $83 \%$.

A demographic questionnaire was intended to furnish the researcher with the respondent's biographical, educational information and working experiences in the managerial position and teaching. Management styles questionnaire was derived from the conceptual framework of Reddin's 3-D theory of management effectiveness styles. According to Reddin, the four styles are more effective when outstanding leaders use Developer, Executive, Bureaucrat, and Benevolent autocrat. This questionnaire consisted of 37 items about four more effective styles. Each statement includes a five-point Likert scale (from very rarely=1 to often=5). Job Satisfaction survey questionnaire - a self-administered job satisfaction questionnaire - was used to assess the level of job satisfaction among teachers according to nine sub-scales (salaries, fringe benefits, recognition, promotion, and communication, working conditions, nature of the job, supervision, and co-workers). This questionnaire had 41 items. Each statement includes a five-point Likert scale (from strongly disagree $=1$ to strongly agree $=6$ ). The content and face validity for the questionnaires confirmed by a panel of experts consisting of management experts and educational administration. Cronbach's alpha coefficient has been preferred for estimating the reliability multi-item scales. An Alpha value of 0.70 value or higher was considered as acceptable reliability for group. To determine the reliability of questionnaires, these questionnaires were surveyed in two time intervals and an alpha coefficient was determined 0.81 for management styles questionnaire and 0.92 for job satisfaction questionnaire. 
All data were analyzed using the Statistical Package for the Social Sciences (SPSS 15). Appropriate statistical procedures for description and inference were used. The missing values were checked prior to further statistical analysis. The differences between groups were tested with the Chi-square, Mann-Whitney and Kruskal Wallis tests. The correlation coefficients were calculated to evaluate the relationship between variables. Forward conditional logistic regression analysis was used to identify the most important predictor domains in global satisfaction. P-value considered less than 0.05 as significant.

\section{Results}

i. How are the management styles of managers in girl high school?

(Hoteling t2 and P-value are shown in following table. There is a significant difference among four-style of Reddin model. (Table 1)

ii. Is there relationship between developer style and teachers' job satisfaction?

There is a significant relationship between developer style of management and job satisfaction $(\mathrm{P}<0.01)$. Therefore, while correlation coefficient is always positive, there is a direct relationship between developer style of management and job satisfaction. (Table 2)

iii. Is there relationship between executive style of management and teachers' job satisfaction?

Correlation coefficient between executive style of management and job satisfaction, showed significant $(\mathrm{P}<0.05)$ and it has been positive, then there is a direct relationship between executive style of management and teachers' job satisfaction.

iv. Is there relationship between benevolent autocrat style and teachers' job satisfaction?

Correlation coefficient between benevolent autocrat style and teachers' job satisfaction is significant $(\mathrm{P}<0.05)$. Regarding that correlation coefficient between benevolent autocrat style and teachers' job satisfaction is negative; therefore, there is a reverse relationship between them. But it is very small, result in weak relationship.

$\mathrm{v}$. Is there relationship between bureaucrat style of management and teachers' job satisfaction?

Correlation coefficient between bureaucrat style of management and job satisfaction, showed significant $(\mathrm{P}<0.05)$ and it has been positive, then there is a direct relationship between bureaucrat style of management and teachers' job satisfaction. (Table 3)

vi. Is there relationship between female managers' style of management and teachers' demographic variables (gender, working experience, education level, and kind of high school)?

T-test showed a significant between developer style and bureaucrat style of management $(\mathrm{P}<0.05)$. Therefore there is difference between teachers' viewpoints based on education level. In other hand, the teachers with master degree pointed that their managers used developer style of management more than others styles. And the teacher with bachelor degree point that their managers used bureaucrat style of management more than other styles.

There was not any difference between teachers' viewpoints based on their education field.

Findings in table 3 showed that the observed t- test is significant particularly about developer style of management. Therefore there is difference between teachers' viewpoint based on teachers' gender, in other hand, female teachers mentioned that their managers have used developer style of management.

There is not any difference between teachers' job satisfaction and gender, education field and education degree, accordingly $\mathrm{P}=0.366, \mathrm{P}=0.954, \mathrm{P}=0.161$.

\section{Discussion}

The results from table (2) about the second question of research showed that correlation coefficient between developer style of management with teachers' job satisfaction is significant $(\mathrm{r}=0.627, \mathrm{P}=0.001, \alpha=0.01)$. Therefore there is a direct relationship between developer styles of management with teachers' job satisfaction. In other hand, those managers who allowed the teachers without regarding their aptitudes and innovations to give suggestions and participate in decisions to provide a silent, secure and trustable workplace for them, these mangers provided more job satisfaction in them. Sellgrens et al. (2006) found that the manager's style can be fundamental for subordinates' acceptance of change and in motivating them to achieve stated visions and goals and high quality of care. Results showed that there are statistically significant differences in opinions of preferred leadership between managers and subordinates, especially related to production and relation orientation.

The results of table (2) about the third question of research showed that correlation coefficient between the executive style of management with teachers' job satisfaction was significant $(r=0.649, p=0.001, \alpha=0.01)$. Then, 
there is direct relationship between executive styles of management with teachers' job satisfaction. In other hand, those managers who emphasizes human relationship, encourage people to work hard, believed in promotion based on people aptitude and abilities, they induce more job satisfaction in the teachers. Because they will be happy for delegating according to their abilities and reward for completing their tasks.

The results of table (2) about third question of research showed that the correlation coefficient between the benevolent autocrat style of management with teachers' job satisfaction was significant $(r=0.221, p=0.013, \alpha=0.01)$. Therefore there is an inverse relationship between the benevolent autocrat styles of management with teachers' job satisfaction. Lucas (1991), in his research on nurses determine nurses' perceptions of the current and desired management styles, found that the staff nurses were currently experiencing a beneolent-authoritative management style, but preferred a participative style. Management style and job satisfaction were significantly correlated $(\mathrm{r}=$ 0.60500). This means that those mangers who have self-confidence and self-trusting and don't maintained informal relations among teachers, don't delegate duties to others, these managers don't induce job satisfaction to the teachers, because doing right things by teachers is more important than their moral and affect the way they run the school without any opposition. In other hand, those mangers who do not consider staff problems and conflicts, administer rules and regulations exactly, do not induce optimum job satisfaction in the teachers, because these managers monitor the teachers and report their lack of discipline inconsiderably. Then it seems that job satisfaction is associated with leadership behavior. This is similar to studies of Bartok (1999), Blood (1968) Wyckoff and Skogan (1994) and Mosadeghrad (2006). From this study, female mangers stated that the managers' style is more than developer style. The overall results showed that, the developer and executive styles of management had more effect on teachers' job satisfaction than others. Also the result clearly shows that teachers' education degree, gender and field of education have influence on determining mangers' management styles. But in many studies have found that employee job satisfaction had correlated with age, gender, marital status, graduation level, and work experiences years (Hallock et al., 2004; Chu et al., 2003; Aronson et al., 2003; Lyons et al., 2003;, Al-Ahmadi, 2002;, Bodur, 2002).

* Isfahan is located on the main north-south and east-west routes crossing Iran, and was once one of the largest cities in the world. It flourished from 1050 to 1722, particularly in the 16th century under the Safavid dynasty, when it became the capital of Persia for the second time in its history. Even today, the city retains much of its past glory. It is famous for its Islamic architecture, with many beautiful boulevards, covered bridges, palaces, mosques, and minarets. This led to the Persian proverb "Esfahān nesf-e jahān ast" (Isfahan is half of the world).

\section{Acknowledgments}

The authors thank Prof. Manjeet Kumar Chaturvedi, Department of Sociology, Banaras Hindu University, Varanasi, India for helpful comments and suggestion on the manuscript.

\section{References}

Alaghaband, Ali. (1998). Theoretical concept and Principles of Educational Administration. Tehran: Beassat Publication.

Al-Ahmadi, H.A. (2002). Job satisfaction of nurses in ministry of Health Hospitals in Riyadh, Saudia Arabia, Saudi Medical Journal, Vol. 23, 645-50. PMid: 12070540

Aronson, K.R., Sieveking, N., Laurenceau, J.P., \& Bellet, W. (2003). Job satisfaction of psychiatric hospital employees: a new measure of an old concern, Adm. Policy Ment. Health, Vol. 35, 51-60

Bartolo, K., \& Furlonger, B. (1999). Leadership and job satisfaction among aviation fire fighters in Australia, Journal of Management Psychology, 15 (10), 87-97

Bass, B.M. (1990). Stogdill's handbook of Leadership: theory, research and managerial applications. Third edition. NewYork: The free Press.

Berson, Y., \& Linton, J.D. (2005). An examination of the leaderships between leadership style, quality and employee satisfaction in $R \& D$ versus administrative environments, R\&D Management, 35, 51-60. doi:10.1111/j.1467-9310.2005.00371.x, http://dx.doi.org/10.1111/j.1467-9310.2005.00371.x

Bodur, S. (2002). Job satisfaction of health care staff employed at health centers in Turkey, Occupational Medicine, London, Vol. 52, 353-5. doi:10.1093/occmed/52.6.353, http://dx.doi.org/10.1093/occmed/52.6.353. PMid:12361997

Bogler, R. (2001). The influence of leadership style on teacher job satisfaction, Educational administration quarterly, 37(5), 662-683. doi:10.1177/00131610121969460, http://dx.doi.org/10.1177/00131610121969460 
Bogler, R. (2002). Two profiles of school teachers: a discriminant analysis of job satisfaction, Teaching and teaching Education, Vol. $\quad 18, \quad 665-673 . \quad$ doi:10.1016/S0742-051X(02)00026-4, http://dx.doi.org/10.1016/S0742-051X(02)00026-4

Chiok Foong Loke, J. (2001). Leadership behaviors: effects on job satisfaction, productivity and organizational commitment, Journal of nursing management, Vol. 9, 4, 191-204. doi:10.1046/j.1365-2834.2001.00231.x, http://dx.doi.org/10.1046/j.1365-2834.2001.00231.x. PMid:11472508

Chu, C., Hsu, H.M., Price, J.L., \& Lee, J.Y. (2003). Job satisfaction of hospital nurses: an empirical test of a causal model in Taiwan, International Nursing Review, Vol. 50, 176-82. doi:10.1046/j.1466-7657.2003.00165.x, http://dx.doi.org/10.1046/j.1466-7657.2003.00165.x. PMid:12930286.

Derlin, R., \& Schneider, G. (1994). Understanding job satisfaction: Principals and teachers. Urban and Suburban, Urban Education, 29(1), 63-88. doi:10.1177/0042085994029001006, http://dx.doi.org/10.1177/0042085994029001006

Dunham-Taylor, J. (2000). Nurse executive transformational leadership found in participative organizations, Journal of nursing administration, vol. 30, 5, 241-50. doi:10.1097/00005110-200005000-00005, http://dx.doi.org/10.1097/00005110-200005000-00005

Filla, K.R., \& Stichler. (2008). Manger and staff Perceptions of the managers leadership style, J.Nurs. Adm, 38(11), 480-487. doi:10.1097/01.NNA.0000339472.19725.31, http://dx.doi.org/10.1097/01.NNA.0000339472.19725.31. PMid:18997553

Hallock, D.E., Salazar, R.J., \& Vennemanw, S. (2004). Demographic and attitudinal correlates of employee satisfaction with an Esop, British Journal of Management, Vol. 15, 321-333. doi:10.1111/j.1467-8551.2004.00422.x, http://dx.doi.org/10.1111/j.1467-8551.2004.00422.x

Hart, P. (1999). Predicting employee life satisfaction: a coherent model of personality, work and non-work experiences, and domain satisfaction, Journal of Applied Psychology, Vol. 84, 564-84. doi:10.1037/0021-9010.84.4.564, http://dx.doi.org/10.1037/0021-9010.84.4.564

Hoppock, R. (1977). Job satisfaction, NewYork: Arno.

Lawler, E. (1973). Motivation in work organization, Brooks/Cole, Monterey, CA.

Locke, E. (1976). The nature and causes of job satisfaction, in Durincetti. M.D. (Ed.), Handbook of industrial and organizationalxpsycology, Rand Mc Nally, Chicago, IL, 1297-349

Lucas. (1991). Management style and staff nurse job satisfaction, J Prof Nurse, Mar-Ap, 7(2), 119-125

Lurnden, L. (1998). Teacher Moral, Eugene, Oh: ERIC Clearing house on Educational Management.

Lyons, K.J., Lapin, J., \& Young, B. (2003). A study of job satisfaction of nursing and allied health graduates from a Mid-Atlantic university, Journal of Allied Health, Vol. 32, 1, 10-17

Mehrotra, A. (2002). A Comparative Study of Leadership Styles of Principals in Relation to Job Satisfaction of Teachers and Organizational Climate in Government and Private Senior Secondary School of Delhi. Unpublished Thesis for Master, University of Delhi.

Mehrotra, A. (2005). Leadership Styles of Principals - Authoritarian and Task Oriented, Mittal Pub, xv, 128 -134

Mosadeghrad, A.M. (2003). Principles of Health care administration, Dibagaran Tehran, Tehran.

Mosadeghrad, A.M., \& Yarmohammadian, M.H. (2006). A study of relationship between managers' leadership and employees' job satisfaction, Leadership in health services, 19(2), pp: xi-xviii

Nealy, S.M., \& Blood, M.R. (1968). Leadership performance of nursing supervisors at two organizational levels, Journal of Applied psychology, Vol. 52, 414-422. doi:10.1037/h0026243, http://dx.doi.org/10.1037/h0026243

Parkinson, K.E. (2008). An examination of the relationship between the perceived leadership style of the principle and late career teacher job satisfaction in selected elementary schools. A doctoral dissertation, University of Arizona.

Sellgren, S. EkVallg, \& Tomson, G. (2006). Leadership styles in nursing management: preferred and perceived, Nursing management, July, 14(5), 345-355

Tsai, C.W. (2008). Leadership style and employees Job satisfaction in international tourist hotels, Advances in culture, Tourism and Hospitality Research, Vol. 2, 293-332. doi:10.1016/S1871-3173(08)02005-3, http://dx.doi.org/10.1016/S1871-3173(08)02005-3

Vance, C., \& Larson, E. (2002). Leadership research in business and health care, J. nurse scholash, Vol. 34, 2, 165-71 
Wetherell, K.M. (2002). Principal leadership style teacher job satisfaction, Unpublished thesis, Doctoral Dissertation, Seton Hall University.

Winter, J.S., \& Sweeney, J. (1994). Improving school climate: Administrators are key: NASP Bulletin, Vol. 7, 65-69. doi:10.1177/019263659407856414, http://dx.doi.org/10.1177/019263659407856414

Wycoff, M.A., \& Skogan, W.G. (1994). the effect of community policy management style on officer' Attitudes, Crime and delinquency, Vol. 40, 371-383. doi:10.1177/0011128794040003005, http://dx.doi.org/10.1177/0011128794040003005

Table 1. The results of Hoteling t 2 and its p-value

\begin{tabular}{|c|c|c|c|c|}
\hline Effect & d.f & F & Value & P-Value \\
\hline Hotelling's Trace & 121 & 35.120393 & 946.3979 & 00.0 \\
\hline
\end{tabular}

Table 2. Correlation coefficient between management styles of managers with Teachers Job Satisfaction

\begin{tabular}{|c|c|c|c|c|}
\hline $\begin{array}{c}\text { Management } \\
\text { Styles }\end{array}$ & $\begin{array}{c}\text { Benelevent } \\
\text { Autocrat }\end{array}$ & Executive & Developer & Bureaucrat \\
\hline Teachers Job Satisfaction & $\mathrm{R}=0.221$ & $\mathrm{R}=0.649$ & $\mathrm{R}=0.627$ & $\mathrm{R}=0.202$ \\
& $\mathrm{P}=0.013$ & $\mathrm{P}=0.001$ & $\mathrm{P}=0.001$ & $\mathrm{P}=0.024$ \\
& $\mathrm{~N}=125$ & $\mathrm{~N}=125$ & $\mathrm{~N}=125$ & $\mathrm{~N}=125$ \\
\hline
\end{tabular}

Table 3. Multi regression relationship between $\backslash$ management styles of managers with Teachers Job Satisfaction

\begin{tabular}{|c|c|c|c|c|c|c|c|c|c|}
\hline $\begin{array}{c}\text { Criteria } \\
\text { Variable }\end{array}$ & $\mathrm{T}$ & Beta & $\mathrm{B}$ & $\mathrm{Sig}$ & $\mathrm{F}$ & $\mathrm{R} 2$ & $\mathrm{R}$ & $\begin{array}{c}\text { Predictive } \\
\text { Variable }\end{array}$ & sig \\
\hline $\begin{array}{c}\text { Job } \\
\text { Satisfaction }\end{array}$ & 3.49 & 0.431 & 1.22 & 0.001 & 54.93 & 0.474 & 0.688 & $\begin{array}{c}\text { Executive } \\
0.001\end{array}$ \\
\hline
\end{tabular}

